\title{
Flank Wear Modelling in High Speed Hard Milling of AISI D2 Steel
}

\author{
Muataz Hazza F. Al Hazza and Khadijah Muhammad
}

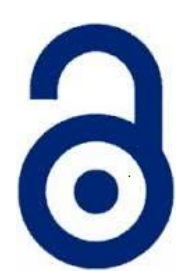

\author{
Received: 07 March 2020 \\ Accepted: 31 May 2020 \\ Published: 30 June 2020 \\ Publisher: Deer Hill Publications \\ (C) 2020 The Author(s) \\ Creative Commons: CC BY 4.0
}

\begin{abstract}
High speed machining has many advantages in reducing time to the market by increasing the material removal rate. However, final surface quality is one of the main challenges for manufacturers in high speed machining due to the increasing of flank wear rate. In high speed machining, the cutting zone is under high pressure associated with high temperature that lead to increasing of the flank wear rate in which affect the final quality of the machined surface. Therefore, one of the main concerns to the manufacturer is to predict the flank wear to estimate and predict the surface roughness as one of the main outputs of the machining processes. The aim of this study is to determine experimentally the optimum cutting parameters: depth of cut, cutting speed $(\mathrm{V} c)$ and feed rate (f) that maintaining low flank wear $(\mathrm{Vb})$. Taguchi method has been applied in this experiment. The Taguchi method has been universally used in engineering analysis. JMP statistical analysis software is used to analyse statically the development of flank wear rate during high speed milling of hardened steel AISI D2 to $60 \mathrm{HRD}$. The experiment was conducted in the following boundaries: cutting speed $200-400 \mathrm{~m} / \mathrm{min}$, feed rate of 0.01-0.05 mm/tooth and depth of cut of 0.1-0.2 $\mathrm{mm}$. Analysis of variance ANOVA was conducted as one of important tool for statistical analysis. The result showed that cutting speed is the most influential input factors with $70.04 \%$ contribution on flank wear.
\end{abstract}

Keywords: AISI D2, High speed hard milling, Taguchi, Flank wear

\section{INTRODUCTION}

High speed hard milling (HSHM) is an advanced machining processes in industry that merges three advanced machining processes: high speed milling, hard milling, and dry milling [1]. Machining above $45 \mathrm{HRC}$ are considered hard machining and usually ranging from 58 to $68 \mathrm{HRC}$ [2]. On the other hand, high speed machining is not the same for all materials, high speed for one material is not considered a high speed for others. HSHM can reduce manufacturing process cost and reducing time to the market. However, there are many challenges that faces the manufacturer in HSHM. One of the main challenges is the increasing of flank wear extremely fast due to the high pressure and high temperature in the cutting zone. Increasing the flank wear of the cutting tool will lead to damaging the final surface roughness. Therefore, estimating and predicting the flank wear rate before the machining process is an essential issue. Tool wear is defined as the amount of volume loss of tool material on the contact surface due to the friction between the cutting tool and workpiece [3]. It will give significant effect on the finished surface, accuracy, manufacturing cost and tool life. Flank wear occurs on the flank face of the tool. This type of wear is basically between the tool and the workpiece. Kalpakjian and Schmid [4] mentioned it happens because the tool is rubbed along the machined surface. Tool and machined parts dimensions vary due to the change and progress of flank wear, thus flank wear need to be controlled. The maximum range accepted for cutting hard materials is $0.3-0.5 \mathrm{~mm}$ [5]. Many researchers studied the output responses of HSHM such as surface roughness [6][7], temperature [8] and flank wear [9]. They investigated the effect of cutting speed, feed rate and depth of cut on the final surface roughness using D2 as a work piece hardened to 52-56 HRC, and coated carbide as cutting tool with higher cutting speed 120-240 $\mathrm{mm} / \mathrm{min}$. They found that the best cutting parameters for minimizing the noise factors were cutting speed of 120 $\mathrm{m} / \mathrm{min}$, feed rate of $0.10 \mathrm{~mm} /$ tooth and depth of cut of $0.10 \mathrm{~mm}$. and the cutting speed is the most significant factor

M.H.F.AL Hazza' $₫$, K. Muhammad²

'Mechanical and Industrial Engineering Department

School of Engineering, American University of Ras AlKhaimah

PO Box 10021, Ras Al Khamiah, UAE

2Department of Manufacturing and Materials Engineering

International Islamic University Malysia

Po Box 10, 50728 Kuala Lumpur, Malaysia

E-mail: muataz.alhazza@aurak.ac.ae

Reference: Al Hazza, M H F and Muhammad, K. (2020). Flank Wear Modelling in High Speed Hard Milling of Machining AISI D2 Steel. International Journal of Engineering Materials and Manufacture, 5(2), 50-54. 
to the flank wear. One of the advantages in high speed hard machining is the power consumption. According to Zhang [10], the energy consumption in high speed machining is lower because of low cutting forces and high removal rate. Dudzinski [11] stated in his writing, this is an important aspect of advanced manufacturing technology to achieve high productivity and to minimize machining cost as the tool life is longer.

In this research, the investigation of the effect of higher cutting speed up to $400 \mathrm{~m} / \mathrm{min}$ on the flank wear rate of hardened steel AISI D2 that hardened to 60-62 HRC and developing a new statistical model based on experimental work that can give valid results to the manufacturer in the boundaries of the research experiment.

\section{Experimental Procedure}

This experiment was conducted using high speed milling in machining hardened steel AISI D2 60-62HRC. The experiment was conducted under dry machining to reduce thermal shock and cutting tool breakage. The chemical composition of AISI D2 is given in Table 1. The machine used in conducting the experiment, the type of material, type of inserts used and other experimental set up is summarized in Table 2.

The cutting tool used in conducting the experiment is AITiN coated carbide (MITSUBISHI VP15TF) and $32 \mathrm{~mm}$ diameter tool holder for end milling produced by MITSUBISHI Company. The specific cutting tool has axial rake angle of $5^{\circ}$ and radial rake angle of $-10^{\circ}$. The thickness of the insert is $3.5 \mathrm{~mm}$, length of $10 \mathrm{~mm}, 6.35$ width and 0.8 $\mathrm{mm}$ corner radius. The stated specifications of the insert are provided in Mitsubishi materials manuals shown in table 3. The specifications of insert (Mitsubishi materials manual, 2015). The experiment has been conducted for three levels and three factors. The experiments were conducted using Taguchi's orthogonal array L9 as a design of experiments.is used in Taguchi method. The cutting parameters and cutting levels are shown in Table 4.

Table 1: Chemical composition of AISI D2

\begin{tabular}{cccccccc}
\hline Composition & $\mathrm{C}$ & $\mathrm{Mn}$ & $\mathrm{Si}$ & $\mathrm{Cr}$ & $\mathrm{Ni}$ & $\mathrm{Mo}$ & $\mathrm{V}$ \\
\hline Wt. \% & $1.40-1.60$ & 0.6 & 0.6 & $11.0-13.0$ & 0.3 & $0.7-1.2$ & 1.1 \\
\hline
\end{tabular}

Table 2: Experimental Set Up

\begin{tabular}{ll}
\hline Machine & VERTICAL CENTER NEXUS 410A-II \\
\hline Material & AISI D2 \\
Dimension of material & $150 \mathrm{~mm} \times 101 \mathrm{~mm} \times 45 \mathrm{~mm}$ \\
Inserts & Mitsubishi VP15TF with AITiN coating \\
Cutting condition & Dry \\
\hline
\end{tabular}

Table 3: Specifications of insert (Mitsubishi materials manual, 2015)

\begin{tabular}{ccccccccc}
\hline $\begin{array}{c}\text { Insert material } \\
\text { and grade }\end{array}$ & ANSI & $\begin{array}{c}\text { Tool } \\
\text { Dia. } \\
(\mathrm{mm})\end{array}$ & $\begin{array}{c}\text { Axial rake } \\
\text { angle } \\
(\stackrel{\circ}{ })\end{array}$ & $\begin{array}{c}\text { Radial } \\
\text { rake angle } \\
\left({ }^{\circ}\right)\end{array}$ & $\begin{array}{c}\text { Insert } \\
\text { thickness } \\
(\mathrm{mm})\end{array}$ & $\begin{array}{c}\text { Insert } \\
\text { length } \\
(\mathrm{mm})\end{array}$ & $\begin{array}{c}\text { Insert } \\
\text { width } \\
(\mathrm{mm})\end{array}$ & $\begin{array}{c}\text { Corner } \\
\text { radius } \\
(\mathrm{mm})\end{array}$ \\
\hline $\begin{array}{c}\text { Coated carbide } \\
\text { VP15TF }\end{array}$ & $\begin{array}{c}\text { AOMT } \\
\text { 184808PEERH }\end{array}$ & 32 & 5 & -10 & 3.5 & 10 & 6.35 & 0.8 \\
\hline
\end{tabular}

Table 4 - Cutting parameters and levels

\begin{tabular}{ccccc}
\hline \multirow{2}{*}{ Parameters } & \multirow{2}{*}{ Unit } & $\mathbf{1}$ & Levels & $\mathbf{2}$ \\
\cline { 3 - 5 } & $\mathrm{m} / \mathrm{min}$ & 200 & 300 & 400 \\
Cutting speed & $\mathrm{mm} /$ tooth & 0.01 & 0.03 & 0.05 \\
Feed rate & $\mathrm{mm}$ & 0.10 & 0.15 & 0.20 \\
Depth of cut & & & \\
\hline
\end{tabular}

\section{RESULTS AND DISCUSSION}

The experimental results from Table 4 were analyzed with analysis of variance (ANOVA), which used for identifying the most affecting the input factors on the performance measures. Figurel shows images of inserts with wear. The images were captured using Nickon optical microscope with 5X magnification. 
Table 3: Orthogonal array L9 of Taguchi experiment design and experimental results

\begin{tabular}{ccccc}
\hline Run & $V_{c}(\mathrm{~m} / \mathrm{min})$ & $f(\mathrm{~mm} /$ tooth $)$ & Depth of cut $(\mathrm{mm})$ & Avg. flank wear $(\mathrm{mm})$ \\
\hline 1 & 200 & 0.01 & 0.1 & 0.0025 \\
2 & 200 & 0.03 & 0.15 & 0.0034 \\
3 & 200 & 0.05 & 0.2 & 0.0069 \\
4 & 300 & 0.01 & 0.15 & 0.0045 \\
5 & 300 & 0.03 & 0.2 & 0.0075 \\
6 & 300 & 0.05 & 0.1 & 0.0063 \\
7 & 400 & 0.01 & 0.2 & 0.009 \\
8 & 400 & 0.03 & 0.1 & 0.0126 \\
9 & 400 & 0.05 & 0.15 & 0.0113 \\
\hline
\end{tabular}

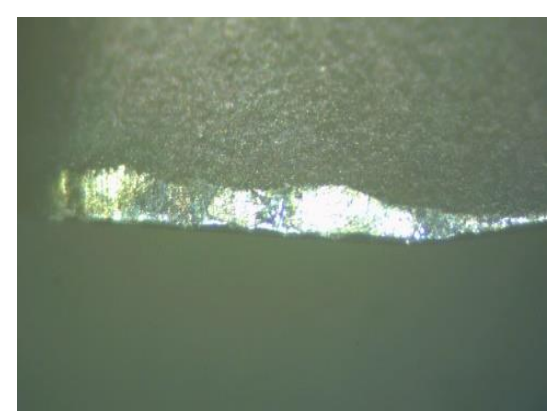

Run 1

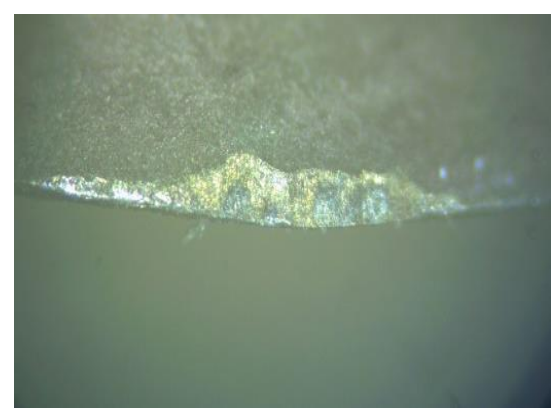

Run 4

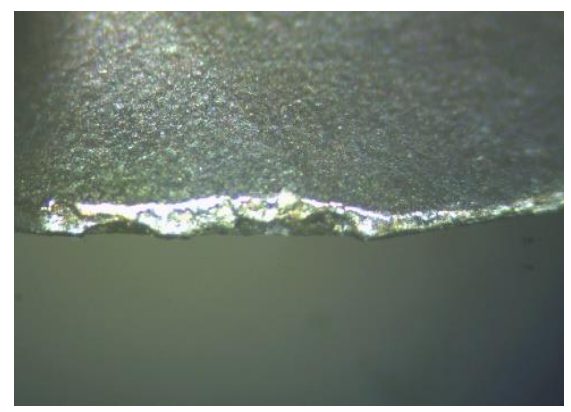

Run 7

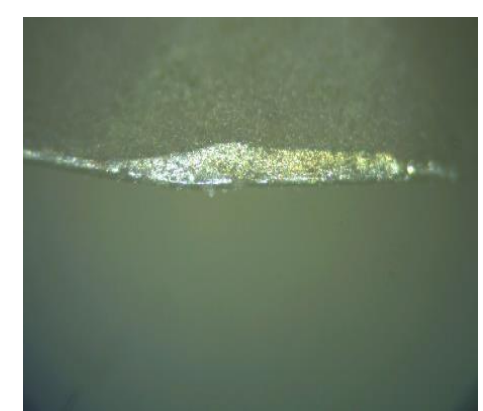

Run 2

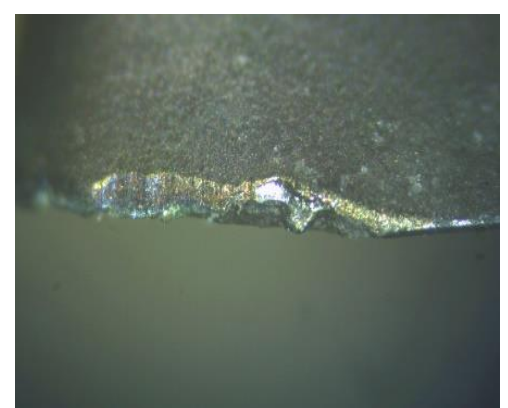

Run 5

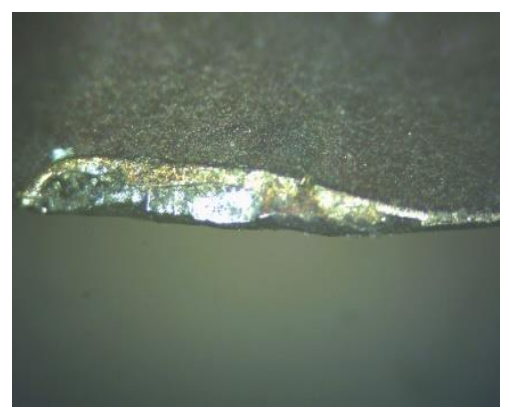

Run 8

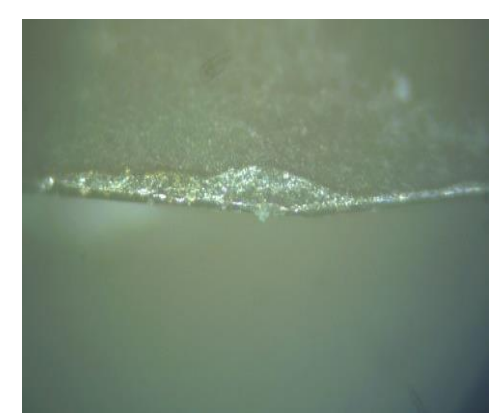

Run 3

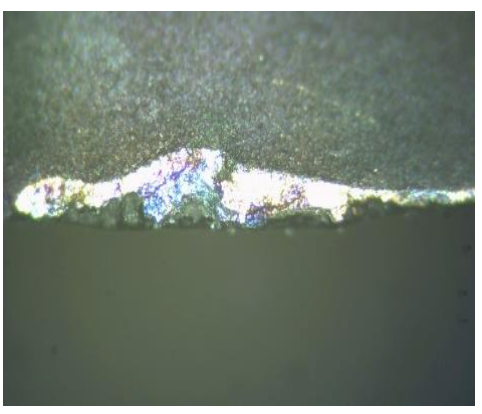

Run 6

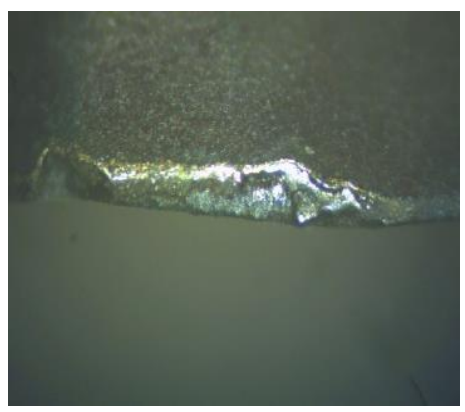

Run 9

Figure 1: Optical images of weared insert 
Table 5 shows the ANOVA result for flank wear analysis. R-Square value for this model is 0.963215 . This indicates that the developed model fits and explains $96.32 \%$ of the variation in flank wear. The Prob $>\mathrm{F}$ value shows that there is only $2.32 \%$ chance error in the developed model due to noise. The model developed is said to be significant at $95 \%$ confidence level as the value of Prob > F less than 0.05 .

F ratio for each cutting parameter is compared to determine the significant cutting parameters. The \% contribution indicated that cutting speed affects flank wear the most with $70.04 \%$ and followed by the cutting feed with $12.21 \%$ of contribution. Depth of cut has $0.39 \%$ contribution and it is said to be insignificant. Feed-depth of cut and speedfeed interaction have a small effect on flank wear rate. The effects are small and not significant to the change of flank wear rate. The statistical model was developed using JMP software has generated the modelling equation for flank wear as follow:

$$
\begin{aligned}
\text { Flank wear }= & -0.0074+(0.00004 * \text { speed })+(0.0713 * \text { feed }) \\
& +(-0.0067 * \text { depth of cut })+(\text { speed }-300) \\
& *[(\text { feed }-0.03) *(-0.0066)]+(\text { feed }-0.03) *[(\text { depth of cut }-0.15) \\
& *(2.1965)]
\end{aligned}
$$

Figure 2 shows the comparison of mean between experimental values and developed model using modelling equation generated by JMP software. Run 3 from Figure 2 has the minimum difference while run 8 has the maximum difference between experimental and developed model values. The variation in flank wear values in due to the

\begin{tabular}{|c|c|c|c|c|c|}
\hline Source & DF & $\begin{array}{l}\text { Sum of } \\
\text { Squares }\end{array}$ & F Ratio & $\begin{array}{c}\% \\
\text { Contribution }\end{array}$ & Remark \\
\hline Cutting Speed & 1 & 0.00006993 & 59.909 & 70.04 & Significant \\
\hline Feed & 1 & 0.00001219 & 10.4422 & 12.21 & Significant \\
\hline Depth of Cut & 1 & 0.00000039 & 0.3335 & 0.39 & Not significant \\
\hline Speed*Feed & 1 & 0.00000371 & 3.1795 & 3.72 & Not significant \\
\hline Speed*Depth of cut & 1 & 0.00001013 & 8.6796 & 10.15 & Not significant \\
\hline Error & 3 & 0.0000035 & & & \\
\hline Total & 8 & 0.00009985 & & & \\
\hline RSquare $=0.963215$ & & Adj $=0.901907$ & & $b>F=0.023$ & \\
\hline
\end{tabular}
presence of noise during machining process such as vibration and random disturbances. The two graphs in Figure 2 show a small deviation between experimental and developed model values.

Table 4: ANOVA for tool wear

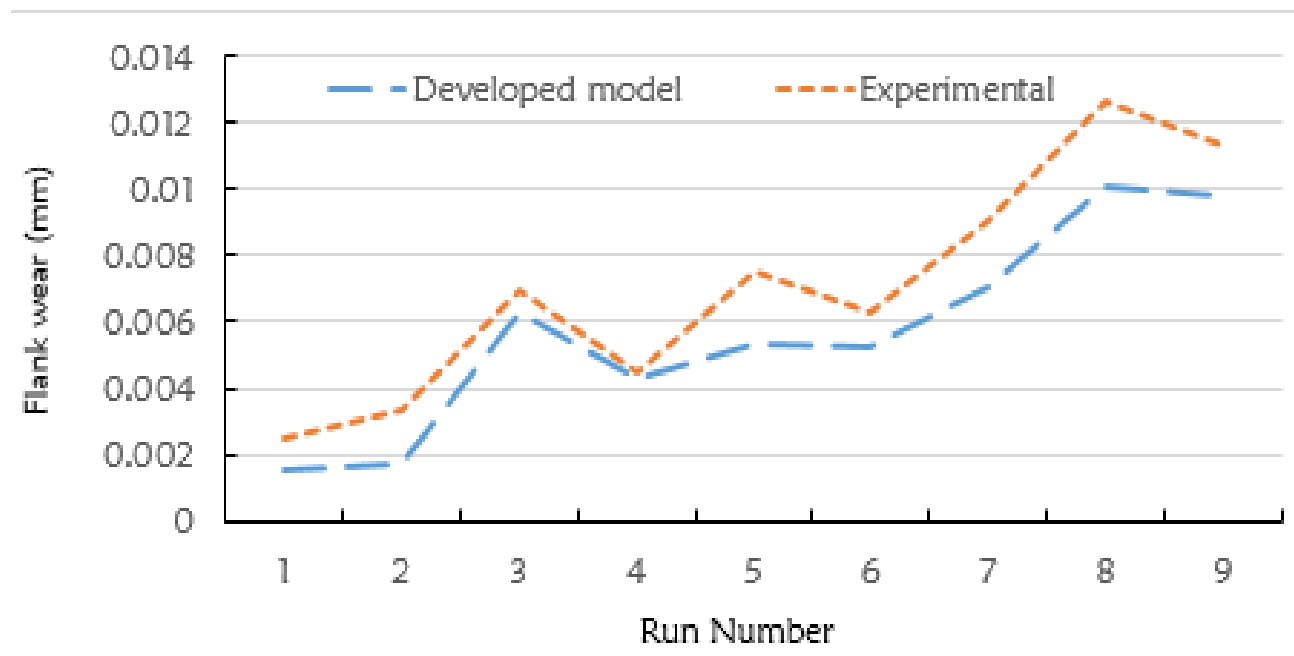

Figure 2: Comparison of mean between developed model and experimental 


\section{CONCLUSIONS}

The results of this study have been analysed and can be concluded by the following:

1. Cutting speed affects flank wear the most. Second influential input factor is cutting feed and effect of depth of cut is said to be insignificant.

2. High speed hard milling is an effective process in reducing the total machining time. However, the flank wear length needs to be monitored and estimated before the machining process to avoid the damage of surface roughness.

3. The new model shows a high accuracy as shown in Figure 1

\section{ACKNOWLEDGEMENT}

The authors are grateful to the Department of Manufacturing and Materials Engineering at International Islamic University Malaysia where this research has been conducted.

\section{REFERENCES}

1. Al-Hazza, M. H. F., \& Bourini, I. F. (2016). Statistical analysis of tooling cost in high speed end milling for hardened steel. Electronic Journal of Applied Statistical Analysis, 9(3), 530-539.

2. Astakhov, V. P. (2011). Machining of hard materials-definitions and industrial applications. In Machining of Hard Materials (pp. 1-32). Springer, London.

3. Zhang, S., Li, J. F., Sun, J., \& Jiang, F. (2010). Tool wear and cutting forces variation in high-speed end-milling Ti6Al-4V alloy. The International Journal of Advanced Manufacturing Technology, 46(1), 69-78.

4. Kalpakjian, S., \& Schmid, S. R. (2014). Manufacturing engineering and technology. K. V. Sekar (Ed.). Upper Saddle River, NJ, USA: Pearson.

5. Davim, J. P. (Ed.). (2011). Machining of hard materials. Springer Science \& Business Media.

6. Cui, X., Zhao, J., Jia, C., \& Zhou, Y. (2012). Surface roughness and chip formation in high-speed face milling AISI H13 steel. The International Journal of Advanced Manufacturing Technology, 61(1-4), 1-13.

7. Al-Hazza, M. H. F., bt Ibrahim, N. A., Adesta, E. T., Khan, A. A., \& Sidek, A. B. A. (2017, March). Surface roughness optimization using Taguchi Method of high-speed end milling for hardened steel D2. In IOP Conference Series: Materials Science and Engineering (Vol. 184, No. 1, p. 012047). IOP Publishing.

8. Zhang, Q., Zhang, S., \& Li, J. (2017). Three-dimensional finite element simulation of cutting forces and cutting temperature in hard milling of AISI H13 steel. Procedia Manufacturing, 10, 37-47.

9. Al-Hazza, M. H. F., bt Ibrahim, N. A., Adesta, E. T., Khan, A. A., \& Sidek, A. B. A. (2017, March). Flank wear analysing of high speed end milling for hardened steel D2 using Taguchi Method. In IOP Conference Series: Materials Science and Engineering (Vol. 184, No. 1, p. 012048). IOP Publishing.

10. Zhang, J. Z., Chen, J. C., \& Kirby, E. D. (2007). Surface roughness optimization in an end-milling operation using the Taguchi design method. Journal of materials processing technology, 184(1), 233-239

11. Dudzinski, D., Devillez, A., Moufki, A., Larrouquere, D., Zerrouki, V., \& Vigneau, J. (2004). A review of developments towards dry and high-speed machining of Inconel 718 alloy. International Journal of Machine Tools and Manufacture, 44(4), 439-456. 